\title{
Adhesive proteins of haemagglutinating Staphylococcus aureus isolated from bovine mastitis
}

\author{
Mats Lindahl, ${ }^{1 *}$ Olof Holmberg ${ }^{2}$ and Per Jonsson ${ }^{1}$ \\ ${ }^{1}$ Swedish University of Agricultural Sciences, Department of Veterinary Microbiology, Section of Bacteriology and \\ Epizootology, Biomedicum, Box 583, S-751 23 Uppsala, Sweden \\ ${ }^{2}$ Swedish University of Agricultural Sciences, Department of Veterinary Microbiology, Section of Clinical Microbiology, \\ Box 7073, S-750 07 Uppsala, Sweden
}

(Received 27 September 1989; revised 12 January 1990; accepted 31 January 1990)

\begin{abstract}
Two proteins derived from the cell wall of Staphylococcus aureus, exhibiting apparent molecular masses of $116 \mathrm{kDa}$ and $145 \mathrm{kDa}$, were found to bind to human buccal and bovine lactiferous sinus epithelial cells. By using antibodies specific for fibronectin-binding protein of $S$. aureus of human origin, the $116 \mathrm{kDa}$ protein, but not the $145 \mathrm{kDa}$ protein, was identified as a fibronectin-binding protein. The $145 \mathrm{kDa}$ protein bound to bovine fat globule membranes, human buccal epithelial cells, bovine lactiferous sinus epithelial cells and sheep erythrocytes. The properties of the $145 \mathrm{kDa}$ protein suggest that it is an adhesin with a possible role in the early stages of the development of bovine mastitis.
\end{abstract}

\section{Introduction}

Bovine mastitis, i.e. inflammation within the mammary glands of dairy cattle, is a serious disease causing heavy economic losses worldwide. Staphylococcus aureus, the most frequent pathogen, gives rise to both acute and chronic forms of mastitis.

Although it is generally believed that bacteria bind to and colonize mucosal surfaces in a specific manner (Christensen et al., 1985) and that $S$. aureus adheres to bovine mammary gland epithelial cells in vitro (Frost $e t$ al., 1977), the pathogenesis of $S$. aureus in the mammary gland is still not fully understood. After transmission of bacteria to the teat orifice and penetration through the teat canal, $S$. aureus cells have to resist the wash-out effect of milking. Experimental infections using low numbers (500 c.f.u.) of $S$. aureus to inoculate teat cisterns $1 \mathrm{~h}$ prior to machine milking give rise to clinical mastitis (P. Jonsson, unpublished data). Such experiments strongly suggest an in vivo adhesion of bacteria to udder epithelial cells.

Another interesting phenomenon of relevance to the pathogenesis of $S$. aureus in the mammary gland has been suggested by Sandholm et al. (1989). They proposed that binding of bacteria to fat globules enables $S$. aureus

Abbreviations: PB, phosphate buffer; PBS, phosphate-buffered saline; SDS-PAGE, SDS-polyacrylamide gradient gel electrophoresis; TBS, Tris-buffered saline. to resist milk flow and distributes bacteria towards the upper regions of the ductular system and of the mammary gland by flotation of the fat globules.

Haemagglutinating properties of $S$. aureus isolated from bovine mastitis have recently been found to be correlated with the ability to adhere to epithelial cells (Lindahl et al., 1989).

The aim of this work was to examine the cell wall of $S$. aureus to establish whether the bacterium produced adhesive factors relevant to pathogenesis.

\section{Methods}

Strain and cultivation. S. aureus strain 14391 was a clinical isolate from a case of acute bovine mastitis in 1985. It was preserved at $-70{ }^{\circ} \mathrm{C}$ in Tryptic soy broth (TSB) containing $15 \%(\mathrm{v} / \mathrm{v})$ glycerol.

Cultivation was done at $37^{\circ} \mathrm{C}$ on nutrient agar supplemented with lactose and trace elements. One litre of medium contained: $3 \mathrm{~g}$ Bacto beef extract (Difco), $5 \mathrm{~g}$ Bacto peptone (Difco), $5 \mathrm{~g} \mathrm{NaCl}, 1 \mathrm{~g}$ lactose, $0.3 \mathrm{~g} \mathrm{Fe}\left(\mathrm{NH}_{4}\right)_{2}\left(\mathrm{SO}_{4}\right)_{2}, 0.015 \mathrm{~g} \mathrm{MnSO}_{4} .4 \mathrm{H}_{2} \mathrm{O}, 0.020 \mathrm{~g} \mathrm{MgSO}_{4} .7 \mathrm{H}_{2} \mathrm{O}$ and $15 \mathrm{~g}$ Bacto agar (Difco).

Haemagglutination. Bacterial cells grown on nutrient agar were collected with sterile cotton swabs and suspended in $0.11 \mathrm{M}$-sodium phosphate buffer (PB), pH 7.4. The optical density at $550 \mathrm{~nm}$ was adjusted to $1 \cdot 0$, which corresponded to $5 \times 10^{8}$ c.f.u. $\mathrm{ml}^{-1}$. Twenty-five microlitres of bacterial suspension was diluted in a twofold series in $U$ shaped wells of a polystyrene microtitre plate (Flow Laboratories) to a dilution of $1 / 64$ in $0.11 \mathrm{M}-\mathrm{PB}, \mathrm{pH} 7.4$. An equal volume of $0.11 \mathrm{M}-\mathrm{PB}$, pH 7.4, was added to each well, as was $25 \mu$ l of erythrocyte suspension (see below).

As a negative control, $25 \mu \mathrm{l}$ of an erythrocyte suspension was 
incubated with 2 vols $0 \cdot 11 \mathrm{M}-\mathrm{PB}, \mathrm{pH} 7 \cdot 4$. After briefly rocking the microtitre plate it was incubated without shaking for $3 \mathrm{~h}$ at $4{ }^{\circ} \mathrm{C}$. Haemagglutination appeared as a mat of erythrocytes covering the bottom of the wells, while in the absence of haemagglutination a red button of sedimented erythrocytes formed in the bottom of the wells. The reciprocal of the highest bacterial dilution giving an unequivocally positive reaction was recorded.

Erythrocytes. Blood from sheep was collected in $1 \%(\mathrm{w} / \mathrm{v})$ sodium citrate and washed three times with 10 vols $0.11 \mathrm{M}-\mathrm{PB}, \mathrm{pH} 7.4$. Erythrocytes were suspended and diluted to a concentration of $5 \times 10^{7}$ cells $\mathrm{ml}^{-1}$.

Epithelial cells. Clinically healthy udders of cows assembled for slaughter were chosen. Udders were excised immediately after slaughter, cleaned, and the required quarters dissected out. The epithelial lining of the ductular system from the streak canal to the ductioles was exposed by cutting with a pair of scissors. The epithelial surface was rinsed several times with $0 \cdot 11 \mathrm{M}-\mathrm{PB}, \mathrm{pH} 7 \cdot 4$, to remove milk.

Epithelial cells were obtained by gentle unidirectional scraping of the surface of the lactiferous sinuses with a soft interdental brush. The brush bearing detached cells was then twirled in $10 \mathrm{ml} 0.14 \mathrm{M}-\mathrm{NaCl}$ containing $0.01 \mathrm{M}$-sodium phosphate buffer (PBS), $\mathrm{pH} 7 \cdot 4$. The same area was not scraped more than eight times to avoid collection of basal membrane cells. Cells were then washed three times in $0.11 \mathrm{M}-\mathrm{PB}$,

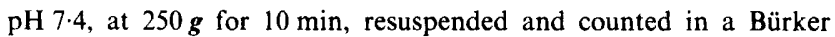
chamber. After final washing the cells were resuspended in the same buffer to approximately $1 \times 10^{6}$ cells $\mathrm{ml}^{-1}$.

Human buccal epithelial cells were gently scraped off with sterile cotton swabs and suspended in 0.11 M-PB, $\mathrm{pH} 7 \cdot 4$. They were washed and diluted as described above for lactiferous sinus epithelial cells.

Periodate treatment. Periodate treatment was performed with $20 \mathrm{~mm}$ periodic acid in cold $0.11 \mathrm{M}-\mathrm{PB}, \mathrm{pH} 6.5$, for $20 \mathrm{~min}$ at $4{ }^{\circ} \mathrm{C}$. Cells were washed in 10 vols $0.11 \mathrm{M}-\mathrm{PB}, \mathrm{pH} 6.5$, and treated with cold $5 \mathrm{~mm}$ $\mathrm{NaBH}_{4}$ for $30 \mathrm{~min}$. After treatment, cells were washed in 10 vols $0.11 \mathrm{M}-\mathrm{PB}, \mathrm{pH} 7.4$, harvested, resuspended and diluted to the initial concentration.

Immunoglobulins. S. aureus strain 14391, grown on nutrient agar, was suspended in saline $\left(2 \times 10^{8}\right.$ bacteria $\left.\mathrm{ml}^{-1}\right)$ and killed by heating for $10 \mathrm{~min}$ at $80^{\circ} \mathrm{C}$. Bacterial cells $\left(1 \times 10^{8}\right)$ in saline were mixed with an equal volume $(0.5 \mathrm{ml})$ of Freund's complete adjuvant. Following collection of preimmune serum, subcutaneous injections were made on three occasions at 2 week intervals. Blood was drawn 2 weeks after the last injection. The serum was applied to a Protein-A Sepharose gel bed and the retained immunoglobulins were eluted with $1 \mathrm{M}$-acetic acid.

Solubilization of the bacterial cell wall. $S$. aureus strain 14391 was cultivated in 2.4 litres of TSB on a rotary shaker at $37^{\circ} \mathrm{C}$ for $6 \mathrm{~h}$. Bacterial cells were sedimented by centrifugation at $6800 \mathrm{~g}$ for $10 \mathrm{~min}$ and washed with $0.2 \mathrm{M}$-potassium phosphate buffer, $\mathrm{pH} 7 \cdot 0$. Pellets were suspended at $0.1 \mathrm{~g}$ (wet weight) bacteria $\mathrm{ml}^{-1}$ in $0.2 \mathrm{M}$-potassium phosphate buffer, $\mathrm{pH} 7.0$, containing $2 \mathrm{~mm}$-phenylmethylsulphonyl fluoride (PMSF) and $5 \mathrm{~mm}$-benzamidine.

After addition of lysostaphin $\left(5 \mu \mathrm{g} \mathrm{ml}^{-1}\right)$, DNAase $\left(5 \mu \mathrm{g} \mathrm{ml}^{-1}\right)$ and $4 \mathrm{mM}^{-} \mathrm{MgSO}_{4}$, the suspension was incubated for $3 \mathrm{~h}$ at $37^{\circ} \mathrm{C}$. Solubilized material was separated from cell debris by centrifugation at $17500 \mathrm{~g}$ for $20 \mathrm{~min}$ at $4{ }^{\circ} \mathrm{C}$. The supernatant fraction was filtered through a $0.22 \mu \mathrm{m}$ Millipore filter and dialysed twice against 1 litre of sample buffer ( $20 \mathrm{~mm}$-sodium phosphate buffer, $\mathrm{pH} 7 \cdot 0$, containing $0.5 \mathrm{M}-\mathrm{NaCl}$ and $1 \mathrm{~mm}$-imidazole) at room temperature for $2 \mathrm{~h}$. Dialysed material was again centrifuged $\left(27000 \mathrm{~g}, 20 \mathrm{~min}\right.$, at $\left.4^{\circ} \mathrm{C}\right)$ before application onto Chelating Sepharose 6B (Pharmacia).
Immobilized metal ion chromatography. Chelating Sepharose 6B was washed according to the instructions of the manufacturer. A column $(18 \times 900 \mathrm{~mm})$ containing $15 \mathrm{ml}$ gel was prepared and loaded with $2.5 \mathrm{ml} 0.2 \mathrm{M}_{-} \mathrm{CuSO}_{4}$ in water. The column was washed with $100 \mathrm{ml}$ water followed by $25 \mathrm{ml} 20 \mathrm{mM}$-sodium phosphate buffer, containing $0.5 \mathrm{M}-\mathrm{NaCl}$ and $20 \mathrm{~mm}$-imidazole ( $\mathrm{pH} 7.0$ ). The column was finally washed with $100 \mathrm{ml} 20 \mathrm{mM}$-sodium phosphate buffer containing $0.5 \mathrm{M}$ $\mathrm{NaCl}$ and $1 \mathrm{~mm}$-imidazole ( $\mathrm{pH} \mathrm{7 \cdot 0)}$ ). The sample was applied, followed by a $200 \mathrm{ml}$ washing step using sample buffer (see above), and then eluted with a $200 \mathrm{ml}$ imidazole gradient $(1-20 \mathrm{~mm})$. Material eluting early (i.e. before $10 \mathrm{~mm}$-imidazole) was pooled and dialysed twice against water and twice against $20 \mathrm{mM}$ Tris $/ \mathrm{HCl}(\mathrm{pH} 7.6)$ containing $0 \cdot 25$ M-taurine.

Ion-exchange chromatography. A Mono Q (HR 5/5) column was used with Beckman System Gold equipment to further purify the material obtained by Chelating Sepharose 6B chromatography. A $5 \mathrm{ml}$ sample in $20 \mathrm{~mm}$-Tris $/ \mathrm{HCl}$ buffer ( $\mathrm{pH} \mathrm{7.6)}$ containing $0.25 \mathrm{M}$-taurine, was applied and eluted with a $50 \mathrm{ml} \mathrm{NaCl}$ gradient $(0 \cdot 2-0 \cdot 5 \mathrm{M})$. The purity of eluted material was analysed by SDS-PAGE, using $10-15 \%$ polyacrylamide gradient gels, in a Pharmacia Phast system. Gels were silver-stained according to the method supplied by the manufacturer.

Agglutination of $S$. aureus with specific IgG. Haemagglutinationpositive $S$. aureus (strain 14391) cells $\left(5 \times 10^{8}\right.$ cells $\left.\mathrm{ml}^{-1}\right)$ in PBS, $\mathrm{pH} 7.4$, were mixed on a glass slide with an equal volume of rabbit IgG specific for purified staphylococcal protein $\left(0.7 \mathrm{mg} \mathrm{ml}^{-1}\right)$ in PBS, $\mathrm{pH} 7.4$. The reaction was recorded after $2 \mathrm{~min}$ in comparison with a similar mixture lacking IgG. Specific IgG were produced as described above, by using $9 \mu \mathrm{g}$ purified staphylococcal protein in Freund's complete adjuvant for each injection.

Binding of solubilized $S$. aureus proteins to erythrocytes and epithelial cells. Sterile-filtered and dialysed lysostaphin lysate of $S$. aureus in PBS, $\mathrm{pH} 7.4(100 \mu \mathrm{l})$, was incubated for $1 \mathrm{~h}$ at room temperature with an equal volume of sheep erythrocytes $\left(5 \times 10^{9} \mathrm{cells} \mathrm{ml}^{-1}\right)$, human buccal epithelial cells or bovine lactiferous sinus epithelial cells $\left(1 \times 10^{6}\right.$ cells $\mathrm{ml}^{-1}$ ). Cells were separated from unbound material by centrifugation at $1800 \mathrm{~g}$ for $20 \mathrm{~min}$ on a $1.5 \mathrm{ml}$ cushion of $10 \%(\mathrm{v} / \mathrm{v})$ Percoll in PBS, $\mathrm{pH} 7 \cdot 4$, solubilized with $2 \%(\mathrm{w} / \mathrm{v})$ sodium dodecyl sulphate and prepared for SDS-PAGE.

Fat globule membranes. Fat globule membranes were prepared as previously described (Lindahl, 1989). Briefly, fresh milk was skimmed by centrifugation at $4000 \mathrm{~g}$ and $4^{\circ} \mathrm{C}$ for $15 \mathrm{~min}$. The collected cream was repeatedly washed by suspension in warm $\left(40^{\circ} \mathrm{C}\right)$ buffer and centrifugation as above. The washed cream was churned and the released fat was removed after centrifugation as above. The remaining fluid was centrifuged at $39000 \mathrm{~g}$ at $4{ }^{\circ} \mathrm{C}$ for $\mathrm{l} \mathrm{h}$ and the resulting pellet containing fat globule membranes was suspended in PBS, $\mathrm{pH} 7 \cdot 4$.

$S D S-P A G E$. SDS-PAGE, with 10-15\% gradient gels, was performed according to Blobel \& Dobberstein (1975). Polypeptides separated by SDS-PAGE were transferred onto nitrocellulose membranes as described by Kijimoto-Ochiai et al. (1985).

Transblots were developed as follows. After quenching for $2 \mathrm{~min}$ in $20 \%(\mathrm{v} / \mathrm{v})$ Tween $20,10 \mathrm{~mm}$-Tris, $\mathrm{pH} 10 \cdot 2$, followed by a $45 \mathrm{~min}$ incubation in PBS, $\mathrm{pH} 6.8$, containing $5 \%(\mathrm{w} / \mathrm{v})$ bovine serum albumin, the nitrocellulose filters were washed in $0.14 \mathrm{M}-\mathrm{NaCl}$ containing $10 \mathrm{~mm}$-Tris/HCl buffer, $\mathrm{pH} 7.6$ (TBS). Preimmune serum (diluted $1 / 400$ ), rabbit IgG raised against heat-killed $S$. aureus, or rabbit IgG Fab fragments specific for $S$. aureus fibronectin-binding protein (supplied by Dr G. Fröman, University of Uppsala, Uppsala, Sweden) $\left(10 \mu \mathrm{g} \mathrm{ml}^{-1}\right)$ in TBS was used as the primary antibody. Incubation was performed for $1 \mathrm{~h}$ at room temperature, followed by washing in TBS, twice, for $10 \mathrm{~min}$. Transblots were then incubated for $1 \mathrm{~h}$ with a biotinconjugated secondary antibody (goat anti-rabbit IgG, Sigma) diluted 
1/400 in TBS. After washing, filters were incubated for $1 \mathrm{~h}$ with peroxidase-conjugated avidin-biotin complex (Dakopatts) followed by washing. Staining was done with a mixture containing 3-aminoethyl-9carbazole

Binding of radiolabelled protein purified from lysostaphin lysates. Purified proteins were radiolabelled using Enzymobeads (Bio-Rad). Protein $(1 \mu \mathrm{g})$ was labelled with $0.5 \mathrm{mCi}(18.5 \mathrm{MBq}) \mathrm{Na}^{125}$ I for $15 \mathrm{~min}$ by the procedure supplied by the manufacturer.

Binding of iodinated proteins to human buccal epithelial cells was done in Minisorp tubes (Nunc). The incubation mixture contained $5 \times 10^{7}$ cells and labelled protein corresponding to between $10^{4}$ and $3 \times 10^{4}$ c.p.m. After incubation, $50 \%(150 \mu \mathrm{l})$ of the mixture was transferred to a new tube with $200 \mu 1$ PBS ( $\mathrm{pH} 7.4$ ), layered on top of $10 \%$ (v v) Percoll in PBS ( $1.5 \mathrm{ml})$ and centrifuged at $1800 \mathrm{~g}$ for $30 \mathrm{~min}$ at $4{ }^{\circ} \mathrm{C}$. The supernatant fraction was discarded and the radioactivity of the resulting pellet was measured in a gamma-counter. Background values were obtained from tubes without cells, but otherwise treated as above. All determinations were made in duplicate.

Iodinated staphylococcal protein was allowed to bind to proteins from fat globule membranes, human buccal epithelial cells and bovine lactiferous sinus epithelial cells, which had been separated on an SDSpolyacrylamide gradient gel and transferred onto nitrocellulose membranes. Transblots were quenched and incubated with a solution containing $4 \times 10^{5}$ c.p.m. iodinated protein $\mathrm{ml}^{-1}$ for $2 \mathrm{~h}$ at room temperature.

Autoradiography was done using Kodak X-AR and an intensifying screen for two weeks.

\section{Results}

Agglutination of sheep erythrocytes by $S$. aureus strain 14391 was detectable with $1.3 \times 10^{6}$ c.f.u. $\mathrm{ml}^{-1}$, or more. Periodate-treated erythrocytes were not agglutinated, even with a bacterial concentration of $1.7 \times 10^{8}$ c.f.u. $\mathrm{ml}^{-1}$. Adhesion of strain 14391 to bovine lactiferous sinus epithelial cells varied between 1 and 5 bacteria per cell, a result that made it difficult to obtain reliable data for further studies using this assay. Adhesion of $S$. aureus to human buccal epithelial cells was usually low (5-10 bacteria per cell), but could occasionally exceed 20 bacteria per cell. Periodate treatment of human buccal epithelial cells did not significantly affect adhesion of strain 14391.

Human buccal epithelial cells and sheep erythrocytes incubated for $60 \mathrm{~min}$ with a lysostaphin lysate of $S$. aureus strain 14391 retained staphylococcal proteins. This was demonstrated by using antibodies against heattreated staphylococcal cells to probe for staphylococcal proteins on transblots of the electrophoretically separated polypeptides (Fig. 1). Human buccal epithelial cells and bovine lactiferous sinus epithelial cells showed no difference with respect to binding of staphylococcal proteins (data not shown). Accordingly, for convenience, human buccal epithelial cells were used in most experiments instead of bovine lactiferous sinus epithelial cells.

Staphylococcal proteins which bound to both human

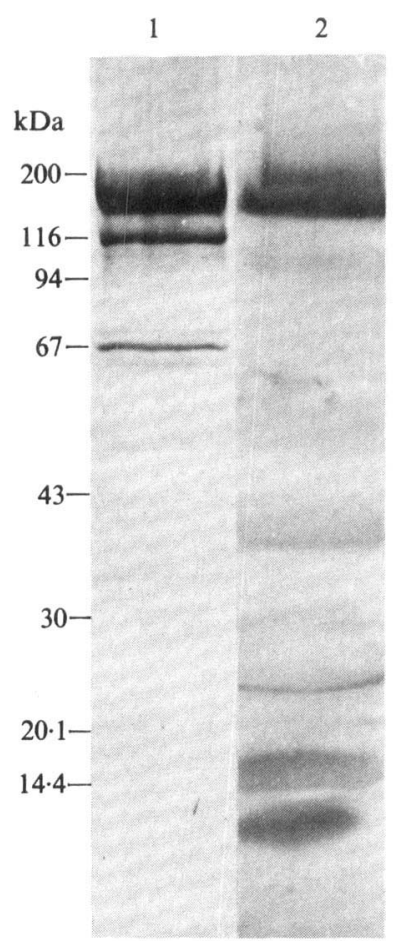

Fig. 1. Western blotting of solubilized human buccal epithelial cells and sheep erythrocytes to which solubilized staphylococcal cell proteins, obtained by lysostaphin treatment, had been allowed to bind. SDS-PAGE was performed and the separated proteins were transferred to nitrocellulose filters. Rabbit IgG raised against heat-killed staphylococcal cells was used as primary antibody to detect staphylococcal polypeptides bound to cells. Lane 1, immunoblot of human buccal epithelial cell proteins; lane 2, immunoblot of sheep erythrocyte proteins. Molecular masses are indicated by the $\mathrm{kDa}$ scale.

buccal and bovine lactiferous sinus epithelial cells exhibited apparent molecular masses of $116 \mathrm{kDa}$ and $145 \mathrm{kDa}$. A staphylococcal protein having an apparent molecular mass of $67 \mathrm{kDa}$ was also detected (Fig. 1). This polypeptide does not, however, bind to epithelial cells, but is present due to its ability to form complexes with other staphylococcal proteins such as the $116 \mathrm{kDa}$ component (data not shown). In a similar experiment, it was shown that the $145 \mathrm{kDa}$ component bound to sheep erythrocytes, whereas the $116 \mathrm{kDa}$ component did not (Fig. 1). Diffuse polypeptide bands below $100 \mathrm{kDa}$ (Fig. 1 , lane 2) originated from proteins of sheep erythrocytes, and were visualized with pre-immune serum or even in the absence of primary antibodies.

Both the $116 \mathrm{kDa}$ and $145 \mathrm{kDa}$ components were purified from lysostaphin lysates of $S$. aureus strain 14391 using immobilized metal ion chromatography and anion-exchange chromatography. The purified 145 and $116 \mathrm{kDa}$ proteins, labelled with $125 \mathrm{I}$, were allowed to bind to human buccal epithelial cells to confirm the existence of binding properties. Significant fractions of 


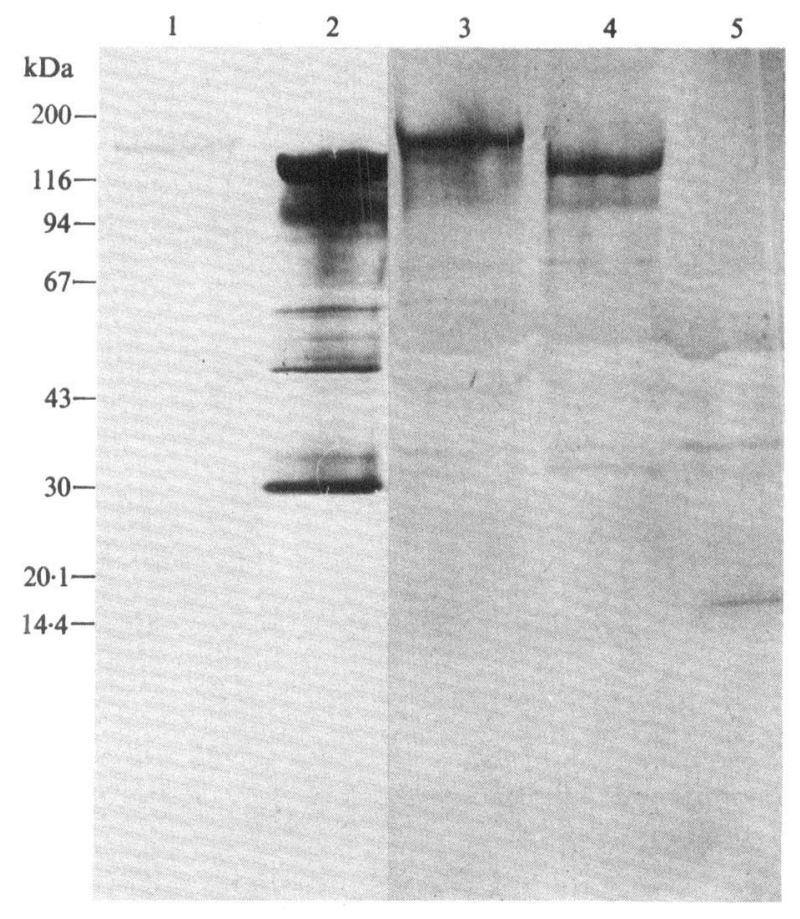

Fig. 2. Western blotting of purified $145 \mathrm{kDa} S$, aureus cell wall component (lane 1), purified $116 \mathrm{kDa} S$. aureus cell wall component (lane 2), solubilized human buccal epithelial cells to which the purified $145 \mathrm{kDa}$ component was allowed to bind (lane 3), solubilized human buccal epithelial cells to which the purified $116 \mathrm{kDa}$ component was allowed to bind (lane 4), and solubilized human buccal epithelial cell proteins as a control (lane 5). SDS-PAGE was performed and the separated proteins were transferred to nitrocellulose membranes. Fab fragments of rabbit IgG specific for staphylococcal fibronectinbinding protein (lanes 1 and 2), or rabbit IgG raised against heat-killed staphylococcal cells (lanes 3-5), were used as primary antibodies. Molecular masses are indicated by the $\mathrm{kDa}$ scale.

the radioactivity added, $9 \cdot 6 \%$ (116 kDa component) and $13.3 \%$ (145 kDa component), were found with the collected cells. Periodate treatment of the human buccal epithelial cells did not significantly affect binding.

The purified staphylococcal components separated by SDS-PAGE and transblotted to nitrocellulose filters were incubated with Fab fragments of rabbit antifibronectin-binding protein (Fröman et al., 1987). Heavy staining of the $116 \mathrm{kDa}$ component was observed, as well as the presence of degradation products, whereas the $145 \mathrm{kDa}$ component was only very weakly stained (Fig. 2). The purified staphylococcal proteins were found to retain their ability to bind to epithelial cells during purification (Fig. 2).

Purified $145 \mathrm{kDa}$ component (Fig. 2) was used to obtain specific antibodies in a rabbit. A strong agglutination of haemagglutination-positive $S$. aureus (strain 14391), using specific IgG, demonstrated the presence of the $145 \mathrm{kDa}$ component on the bacterial cell wall.

Polypeptides of bovine fat globule membranes, human

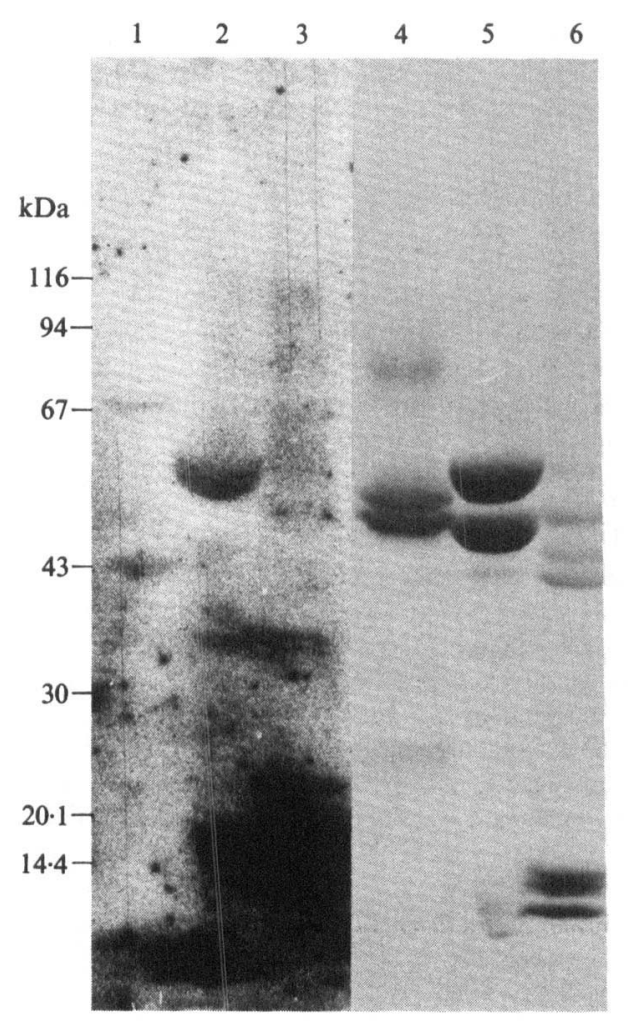

Fig. 3. Separation by SDS-PAGE of $20 \mu \mathrm{g}$ bovine fat globule membrane proteins (lanes 1 and 4), solubilized proteins from $2.8 \times 10^{4}$ human buccal epithelial cells (lanes 2 and 5) and solubilized proteins from $2.5 \times 10^{4}$ bovine lactiferous sinus epithelial cells (lanes 3 and 6 ). A transblot (lanes 1-3) was incubated with ${ }^{125}$ I-labelled $145 \mathrm{kDa}$ component $\left(4 \times 10^{5}\right.$ c.p.m. ml $\left.{ }^{-1}\right)$. Binding was visualized by autoradiography. Coomassie brilliant blue was used to stain the gel for comparison (lanes 4-6). Molecular masses are indicated by the $\mathrm{kDa}$ scale.

buccal epithelial cells and bovine lactiferous sinus epithelial cells were separated by SDS-PAGE. Two sets of samples were run on the same gel. One part of the gel was electrophoretically transblotted to a nitrocellulose membrane, while the other part, with the same set of samples, was stained with Coomassie brilliant blue (Fig. 3). After autoradiography, the transblot, to which the radiolabelled $145 \mathrm{kDa}$ component had been allowed to bind, displayed a few bands. The $145 \mathrm{kDa}$ staphylococcal protein bound to components of fat globule membranes $(65 \mathrm{kDa}$ and $45 \mathrm{kDa})$, human buccal epithelial cells ( $52 \mathrm{kDa})$ and bovine lactiferous sinus epithelial cells (15 kDa and $13 \mathrm{kDa}$ ) (Fig. 3).

\section{Discussion}

Current theories concerning the development of mastitis caused by $S$. aureus suggest colonization of the teat canal or skin as a prerequisite for the infection of the 
mammary gland. Adhesion of $S$. aureus, which has been a matter of dispute for more than a decade (Anderson, 1978; Frost et al., 1977) is likely to occur, at least in the teat canal. The events following entry of bacteria into the teat cistern, which lead to the development of clinical symptoms of mastitis, are yet to be explained. Interesting ideas such as 'hitch-hiking' on rising cream particles (Sandholm et al., 1989) and the possibility that fibronectin might serve as an epithelial receptor for a staphylococcal surface protein have been presented (Fröman $e t$ al., 1987; Mamo et al., 1988). However, more information is still needed to elucidate the pathogenesis of $S$. aureus in the bovine udder. The recent discovery of haemagglutinating properties of $S$. aureus points to the possibility of an adhesive factor with specificity for components other than fibronectin (Lindahl et al., 1989).

Haemagglutination by $S$. aureus does not occur with periodate-treated erythrocytes, indicating the presence of a carbohydrate-specific haemagglutinin. Moreover, the correlation found between haemagglutinating properties and the ability of $S$. aureus to adhere to epithelial cells suggests that the haemagglutinin might be an additional virulence determinant (Lindahl et al., 1989).

Two proteins present in lysostaphin lysates of $S$. aureus have the capacity to bind to human buccal epithelial cells and bovine lactiferous sinus epithelial cells. Thus, they might both act as adhesins. One of them having an apparent molecular mass of $116 \mathrm{kDa}$, is recognized by antibodies specific for the fibronectin-binding protein of $S$. aureus (strain Newman) and only binds to epithelial cells. The $145 \mathrm{kDa}$ component does not react with antibodies to $S$. aureus fibronectin-binding protein, but has the capacity to bind to epithelial cells as well as to fat globule membranes and sheep erythrocytes.

Since the only component present in lysostaphin lysates of $S$. aureus having the capacity to bind to sheep erythrocytes is the $145 \mathrm{kDa}$ protein, this component is likely to be the haemagglutinin. Its receptor would be of a carbohydrate nature since periodate-treated erythrocytes were not agglutinated. Binding of the $145 \mathrm{kDa}$ protein occurred to proteins of diverse molecular mass present on fat globule membranes, human buccal epithelial cells and bovine lactiferous sinus epithelial cells; this could be explained if a similar carbohydrate structure is present on these proteins. The $145 \mathrm{kDa}$ protein may be an adhesin that enables initial colonization of the epithelium of the bovine mammary gland by $S$. aureus. Furthermore, the discovery of this component, which binds to fat globule membrane proteins, supports the hypothesis that $S$. aureus uses fat globules as a vehicle for efficient dissemination in the mammary gland (Sandholm et al., 1989).

We thank L. Eriksson for excellent technical assistance. This study was supported by the Swedish Council for Forestry and Agricultural Research (536-84D151 and 606-85D204).

\section{References}

ANDERSON, J. C. (1978). Absence of bacterial adherence in the establishment of experimental mastitis in mice. Veterinary Pathology 15, 770-775.

Blobel, G. \& Dobberstein, B. (1975). Transfer of proteins across membranes. I. Presence of proteolytically processed and unprocessed nascent immunoglobulin light chains on membrane bound ribosomes of murine myeloma. Journal of Cell Biology 67, 835-851.

Christensen, G. D., Simpson, W. A. \& Beachey, E. H. (1985). Microbial adherence in infection. In Principles and Practice of Infectious Diseases, 2nd edn, pp. 6-23. Edited by G. L. Mandell, R. G. Douglas \& J. Bennet. New York: Wiley.

Fröman, G., Switalski, L. M., Speziale, P. \& HööK, M. (1987). Isolation and characterization of a fibronectin receptor from Staphylococcus aureus. Journal of Biological Chemistry 262, 65646571.

Frost, A. J., Wanasinghe, D. D. \& Woolcock, J. B. (1977). Some factors affecting selective adherence of micro-organisms in the bovine mammary gland. Infection and Immunity 15, 245-253.

KiJimoto-Ochial, S., KatagiRI, Y. U. \& OCHIAI, H. (1985). Analysis of $\mathrm{N}$-linked oligosaccharide chains of glycoproteins on nitrocellulose sheets using lectin-peroxidase reagents. Analytical Biochemistry 147, 222-229.

LINDAHL, M. (1989). Binding of F41 and K99 fimbriae of enterotoxigenic Escherichia coli to glycoproteins from bovine and porcine colostrum. Microbiology and Immunology 33, 373-379.

LiNDAHL, M., JoNSSON, P. \& MÅRD, P.-A. (1989). Hemagglutination of Staphylococcus aureus. Studies on strains isolated from bovine mastitis. Acta Pathologica, Microbiologica et Immunologica Scandinavica 97, 175-180.

MAMO, W., FröMAN, G. \& WADSTRÖM, T. (1988). Interaction of subepithelial connective tissue components with Staphylococcus aureus and coagulase-negative staphylococci from bovine mastitis. Veterinary Microbiology 18, 163-176.

Sandholm, M.,' Kaartinen; L., Hyvönen, P., Veijalainen, K. \& KousA, P. L. (1989). Flotation of mastitis pathogens with cream from subclinically infected quarters. Prospects for developing a cream-raising test for detecting mastitis caused by major mastitis pathogens. Journal of Veterinary Medicine B36, 27-34. 